\title{
Cytotoxicity and Apoptosis Induction of Ardisia crispa and Its Solvent Partitions against Mus musculus Mammary Carcinoma Cell Line (4T1)
}

\author{
Muhammad Luqman Nordin, ${ }^{1}$ Arifah Abdul Kadir, ${ }^{1}$ Zainul Amiruddin Zakaria, \\ Fauziah Othman, ${ }^{3,4}$ Rasedee Abdullah, ${ }^{5}$ and Muhammad Nazrul Hakim Abdullah ${ }^{2}$ \\ ${ }^{1}$ Department of Veterinary Preclinical Sciences, Faculty of Veterinary Medicine, Universiti Putra Malaysia (UPM), 43400 Serdang, \\ Selangor, Malaysia \\ ${ }^{2}$ Department of Biomedical Sciences, Faculty of Medicine and Health Science, Universiti Putra Malaysia (UPM), 43400 Serdang, \\ Selangor, Malaysia \\ ${ }^{3}$ Department of Human Anatomy, Faculty of Medicine and Health Sciences, Universiti Putra Malaysia (UPM), 43400 Serdang, \\ Selangor, Malaysia \\ ${ }^{4}$ Prof. Fauziah Biohealth Sdn. Bhd, Malaysia \\ ${ }^{5}$ Department of Veterinary Pathology and Microbiology, Faculty of Veterinary Medicine, Universiti Putra Malaysia (UPM), \\ 43400 Serdang, Selangor, Malaysia
}

Correspondence should be addressed to Arifah Abdul Kadir; arifah@upm.edu.my

Received 14 December 2016; Revised 9 February 2017; Accepted 22 February 2017; Published 16 March 2017

Academic Editor: Victor Kuete

Copyright ( $) 2017$ Muhammad Luqman Nordin et al. This is an open access article distributed under the Creative Commons Attribution License, which permits unrestricted use, distribution, and reproduction in any medium, provided the original work is properly cited.

\begin{abstract}
This study was conducted to investigate the cytotoxicity and apoptosis effect of $A$. crispa extract and its solvent partition (ethyl acetate and aqueous extract) against Mus musculus mammary carcinoma cell line (4T1). The normal mouse fibroblast cell line (NIH3T3) was used as comparison for selective cytotoxicity properties. The cytotoxicity evaluation was assessed using MTT assay. $\mathrm{AO} / \mathrm{PI}$ dual fluorescent staining assay and Annexin V-FITC were used for apoptosis analysis. Results showed that $80 \%$ methanol extract from leaves showed most promising antimammary cancer agent with IC50 value of $42.26 \pm 1.82 \mu \mathrm{g} / \mathrm{mL}$ and selective index (SI) value of 10.22. Ethyl acetate was cytotoxic for both cancer and normal cell while aqueous extract exhibited poor cytotoxic effect. $4 \mathrm{~T} 1$ cells labelled with AO/PI and Annexin V-FITC and treated with 80\% methanol extract demonstrated that the extract induces apoptosis to $4 \mathrm{~T} 1 \mathrm{mammary}$ cancer cells. In conclusion, $80 \%$ methanol extract of $A$. crispa was selectively cytotoxic towards $4 \mathrm{~T} 1 \mathrm{cells}$ but less cytotoxic towards NIH3T3 cells and induced the cancerous cells into apoptotic stage as early as 6 hours.
\end{abstract}

\section{Introduction}

Ardisia crispa (Thunb.) A. DC., a family member of Myrsinaceae, is a plant that is widely distributed over Asian countries including Malaysia, Japan, India, and Indonesia. This plant is known by variety of names such as Coral Ardisia, Coral Bush, Christmas Berry, and Hen's eyes. Local Malaysian people often call this plant "pokok Mata Ayam." Traditionally, the roots of the plant were boiled and have been used for herbal preparation for treatment of numerous human ailments. The roots of this plant species were claimed by traditional practitioners to possess numerous therapeutic benefits such as ability to treat fever, rheumatism, cough, diarrhoea, menstrual pain, pain, insect bites, and swelling and to improve general blood circulation. Scientific studies conducted mostly focus on the root of the A. crispa and there is still little information about the effect from other parts of the plant such as from its leaves. Previous scientific studies have demonstrated numerous biological activities of A. crispa particularly in its root part including antipyretic [1], anti-inflammatory and antihyperalgesic [2,3], antiulcer [4], and anticancer (skin and liver) activities [5-7]. Mammary 
cancer is the most leading cancer among females globally [8]. Mammary cancer can affect animal and human and it is cancer that arises from mammary gland. In human, due to anatomical location of mammary gland in breast, it is called breast cancer. However, the incidence of mammary cancer in males is extremely low (less than $1 \%$ ). Indeed, many studies have been conducted worldwide in order to discover the new potential source of anticancer and medicinal plants seem to provide a source of anticancer agents $[3,9]$.

Mus musculus mammary carcinoma (4T1) cell is a type of animal model of mammary carcinoma and can be induced in $\mathrm{BALB} / \mathrm{c}$ mice. This type of cancer cell has gained attention from many researchers because it closely mimics stage IV human breast cancer and an alternative study about human breast cancer using animal model of cancer cell. However, to the best of our knowledge, no one has conducted any scientific evaluations of $A$. crispa on malignant mammary cancer and normal cell with the mode of cancer death. Previous studies particularly focused on root part of the plant and none reported on the leaves. Now, the aim of this study is to evaluate the anticancer potentials from the leaves of $A$. crispa.

\section{Materials and Methods}

2.1. Collection and Identification. A. crispa leaves were collected from Biodiversity Unit, Universiti Putra Malaysia, and certified by botanist of the Institute Bioscience (IBS), Universiti Putra Malaysia (UPM), Serdang, Selangor, Malaysia, by comparing with deposited specimens (SK 2834/15) from Herbarium of Natural Products, IBS, UPM. The leaves were cleaned and then dried in oven at $37^{\circ} \mathrm{C}$ for 7 days.

2.2. Preparation of Extracts. Leaves from A. crispa were cleaned with tab water and dried in oven for a week. The leaves then pulverized using commercial blender (model HGB2WTS3). Pulverized leaves (200 g) were soaked with $80 \%$ methanol (hydromethanol extraction) for 72 hours at room temperature. The solvent-containing extracts were evaporated under reduced pressure by using a vacuum rotary evaporator (Heidolph Germany) and controlled heating bath at $30^{\circ} \mathrm{C}$. The yield that was obtained was further dissolved and extracted with ethyl acetate and aqueous extract in Soxhlet extractor. The yield that was obtained was then stored at $-20^{\circ} \mathrm{C}$ until used for analysis.

2.3. Cell Line and Culture Medium. Mus musculus mammary carcinoma cancer cell line (4T1) was gleaned from American Type Culture Collection (ATCC), USA. The cells were cultured in Roswell Park Memorial Institute (RPMI-1640) medium without phenol red. All the media were supplemented with $10 \%$ fetal bovine serum (FBS), 1\% antibioticantimycotic $\left(\mathrm{Gibco}^{\circledR}\right.$, Thermo Fisher Scientific) as a complete growth medium (CGM). The cells were thawed gradually from liquid nitrogen to $-80^{\circ} \mathrm{C}$ freezer and then $37^{\circ} \mathrm{C}$ water bath prior to culture with $5 \%$ carbon dioxide $\left(\mathrm{CO}_{2}\right)$ in incubator at $37^{\circ} \mathrm{C}$. The cells were checked daily for viability, proliferation, and confluency.
2.4. In Vitro Cytotoxicity Assay. The confluent $4 \mathrm{~T} 1$ cells were detached and harvested with $0.25 \%$ trypsin (1x). Briefly, $100 \mu \mathrm{L}$ of media containing $1 \times 10^{4}$ cells was seeded in 96well plates. The plate was incubated overnight to allow cell attachment to the bottom of the well plates. After overnight incubation, old media were removed. The extracts were dissolved in dimethyl sulfoxide (DMSO) with the highest concentration of DMSO which is $0.2 \%$. The cells then were treated with extracts at concentration of 1000, 500, 250, 125, $62.5,31.25$, and $15.63 \mu \mathrm{g} / \mathrm{mL}$. Each concentration of treated cells, untreated cells $(0 \mu \mathrm{g} / \mathrm{mL})$, and blank was performed in triplicate in one plate and the experiment was repeated for three times for validity. The plates were further incubated for 72 hours. After 72 hours of treatment period, the old media were removed and replaced with $100 \mu \mathrm{L}$ of fresh medium. $20 \mu \mathrm{L}$ of filtered MTT solution ( $5 \mathrm{mg} / \mathrm{mL}$ PBS) was added to each well. The plates were wrapped with aluminium foil and incubated again for 3 hours at $37^{\circ} \mathrm{C}$ with $5 \% \mathrm{CO}_{2}$. Carefully, $110 \mu \mathrm{L}$ medium was aspirated from each well and, then, $100 \mu \mathrm{L}$ of DMSO was added to each well and mixed thoroughly with pipette. The plates were reincubated for another 10 minutes. The optical density (OD) was measured using spectrophotometer (Infinite M200 PRO) at $570 \mathrm{~nm}$ after 10 minutes of incubation.

The percentage of cell viability (\%) was calculated using the formula:

$$
\begin{aligned}
& \text { Cell viability (\%) } \\
& \begin{aligned}
=\frac{\text { mean OD of treated cell }- \text { mean OD of blank }}{\text { mean OD of untreated cell }- \text { mean OD of blank }} \\
\quad \times 100
\end{aligned}
\end{aligned}
$$

The cytotoxic effects against $4 \mathrm{~T} 1$ cells after 72 hours were recorded as $\mathrm{IC}_{50}$ compared with untreated cells $[10,11]$. The percentages of cell viability values against concentration of respective extracts were plotted in order to determine the $\mathrm{IC}_{50}$ values of each extract. The $\mathrm{IC}_{50}$ value refers to the concentration of the extract able to inhibit $50 \%$ of the cells population. The comparison between treated cells and untreated cell was evaluated by using one-way ANOVA followed by Dunnett's multiple comparison tests. Significant difference was considered accepted at $P<0.05$.

2.5. Selectivity Index of A. crispa and Its Partitions. The selectivity indexes (SI) of HEAC, EAEAC, and AQEAC were estimated according to the method described in [12] with slight modification which were as follows:

$$
\mathrm{SI}=\frac{\mathrm{CC}_{50}}{\mathrm{IC}_{50}},
$$

where SI is selectivity index. $\mathrm{CC}_{50}$ is minimum cytotoxic concentration that allows at least $50 \%$ cells to survive. $\mathrm{IC}_{50}$ is minimum inhibitory concentration that kills at least $50 \%$ of cells.

Normal mouse fibroblast cell line (NIH3T3) was used as comparison for extract with $4 \mathrm{~T} 1$ mammary cancer cells. The NIH3T3 cell line was gleaned from ATCC and was grown 
in RPMI 1640 medium with L-glutamine, supplemented with $10 \%$ fetal bovine serum (FBS) (Gibco, 1\% antibioticantimycotic) $(10,000$ units $/ \mathrm{mL}$ of penicillin, $10,000 \mu \mathrm{g} / \mathrm{mL}$ of streptomycin, and $25 \mu \mathrm{g} / \mathrm{mL}$ amphotericin B) as a complete growth medium (CGM).

2.6. Phytochemical Screenings. The test was conducted to detect the presence of phytochemical constituents of the extracts including phenolics, flavonoids, alkaloids, saponins, tannins, and terpenoids which are well known to have multiple biological properties such as antioxidant, antimicrobial, and anticancer properties [13-15].

2.6.1. Detection of Phenolics. Five milliliters of sterile distilled water was added to $0.5 \mathrm{~mL}$ of HEAC, EAEAC, and AQEAC in test tubes. Five drops of $1 \%$ ferric chloride $\left(\mathrm{FeCl}_{3}\right)$ solution were added to the test tubes and allowed to mix. The formation of bluish black solution indicates presence of phenols [16].

2.6.2. Detection of Flavonoids. The flavonoids detection was based on alkaline reagent test described in [17] with slight modification. Three milliliters of HEAC, EAEAC, and AQEAC was mixed with $1 \mathrm{~mL}$ of $10 \%$ sodium hydroxide $(\mathrm{NaOH})$ solution in test tubes. Development of intense yellow, which becomes colourless on addition of dilute acid, indicates the presence of flavonoids.

2.6.3. Detection of Saponins. The saponins detection was based on froth test described in [16]. Half milliliters extract was mixed with $2 \mathrm{~mL}$ of distilled water in test tube and then mixed thoroughly. The presence of saponins was detected by consistence of the froth formation for 10 minutes.

2.6.4. Detection of Tannins. The tannins detection was based on method described in [18]. $0.5 \mathrm{~mL}$ of HEAC, EAEAC, and AQEAC were dissolved in $20 \mathrm{~mL}$ distilled water in a test tube. The mixed solutions were filtered with Whatman Number 1 filter paper. The $2 \mathrm{~mL}$ of filtrated solutions was treated with $1 \%$ ferric chloride $\left(\mathrm{FeCl}_{3}\right)$ solution. Blackish-blue or blackish green indicates the presence of tannins.

2.6.5. Detection of Terpenoids. Terpenoids detection was based on method described in [19]. $0.5 \mathrm{~mL}$ of HEAC, EAEAC, and AQEAC was mixed with $3 \mathrm{~mL}$ of chloroform. Then $3 \mathrm{~mL}$ of concentrated sulfuric acid $\left(\mathrm{H}_{2} \mathrm{SO}_{4}\right)$ was carefully added drop by drop to each extract to form layers. Positive availability is when reddish brown colouration layer is formed.

2.7. Acridine Orange/Propidium Iodide (AO/PI) Dual Fluorescent Staining Assay. The presence of apoptosis event was observed using acridine orange/propidium iodide (AO/PI) dual fluorescent staining assay. $2 \times 10^{5} 4 \mathrm{~T} 1$ mammary cancer cells were seeded into two $25 \mathrm{~cm}^{2}$ sterile flasks and $4 \mathrm{~mL}$ of complete media was added. One of the flasks was a control (untreated cells). The flasks were incubated overnight in incubator at $37^{\circ} \mathrm{C}$ with $5 \% \mathrm{CO}_{2}$ supplementation. The next day, the old media in one flask were aspirated out, followed with washing with $5 \mathrm{~mL}$ of phosphate buffer saline (PBS) and replaced with new media with treatment. In another flask, the same procedure was repeated but $4 \mathrm{~mL}$ of new media was added without treatment. Both flasks were incubated for 72 hours at $37^{\circ} \mathrm{C}$ with $5 \% \mathrm{CO}_{2}$ supplementation. The concentration of treatment was based on the $\mathrm{IC}_{50}$ of $80 \%$ methanol extract. After 72 hours of treatment time, the old media were aspirated into $15 \mathrm{~mL}$ centrifuge tubes. The flasks were washed with cold PBS slowly and then were aspirated into the same centrifuge tubes. The attached cells in flasks also were detached with $0.25 \%$ EDTA trypsin and the detached cells were aspirated into the same $15 \mathrm{~mL}$ centrifuge tube containing the old media, PBS, and trypsinized cells. The collected cells in $15 \mathrm{~mL}$ centrifuge tube were centrifuged at $1200 \mathrm{rpm}$ for 5 minutes. The supernatants were aspirated out. Ten microliters $(10 \mathrm{mg} / \mathrm{mL})$ of acridine orange (AO) and $10 \mu \mathrm{L}(1 \mathrm{mg} / \mathrm{mL})$ of propidium iodide (PI) were added to centrifuge tube and resuspended. The mixtures were incubated for 10 minutes in dark room at room temperature. Finally, after 10 minutes of incubation time, $10 \mu \mathrm{L}$ of mixture solution was aspirated and placed onto microscope slide and covered with coverslip. The slides were viewed under inverted research fluorescence microscope (Nikon ECLIPSE Ti-S, Shinagawa-ku, Tokyo, Japan) at 20x magnification.

\subsection{Quantitative Apoptosis Analysis Using Flow Cytometer. 5} $\times 10^{5} 4 \mathrm{~T} 1$ mammary cancer cells were seeded into $25 \mathrm{~cm}^{2}$ sterile flasks and $4 \mathrm{~mL}$ of complete media was added to the flasks to allow cells attachment overnight. The next day, the old media were removed and the cells were treated with HEAC according to its $\mathrm{IC}_{50}$ concentration and further incubated for 6 and 24 hours. The detection of apoptotic cells was performed based on protocol described by ApoDetect ${ }^{\mathrm{TM}}$ Annexin V-FITC Kit (Invitrogen), catalogue number 331200. After 6 and 24 hours of incubation times, the old media were aspirated by serological pipette onto $15 \mathrm{~mL}$ centrifuge tube. The flasks then were washed with cold PBS and the liquids were aspirated again onto the same centrifuge tube. One milliliter of $0.25 \%$ EDTA trypsin was added to the flasks to detach the remaining cells. The trypsinized cells were aspirated and collected to the same centrifuge tubes. The centrifuge tubes then were spun down at $3000 \mathrm{rpm}$ for 1 minute. The supernatants were gently removed. Briefly, $100 \mu \mathrm{L}$ binding buffer was added and mixed gently to the cells by tapping with hand. Ten microliters of Annexin VFITC and $10 \mu \mathrm{L}$ propidium iodide $(20 \mu \mathrm{g} / \mathrm{mL})$ were added to cells suspension and resuspended gently. The mixtures were incubated 10 minutes at room temperature. Then, the cells were washed with $400 \mu \mathrm{L}$ binding buffer, sequentially centrifuged at $3000 \mathrm{rpm}$ for 1 minute. The supernatants were removed and $200 \mu \mathrm{L}$ binding buffer was added again. The samples were filtered through $50 \mu \mathrm{L}$ nylon mesh before being transferred into $12 \times 75 \mathrm{~mm}$ tubes. The apoptosis analyses of treatment and control samples were run using flow cytometry 10,000 cells per event.

2.9. Statistical Analysis. All the percentages of cell viability were expressed as mean $(n=3)$ per plate \pm SD (standard deviation) and differences among treated and untreated cells 
TABLE 1: Percentage (\%) of cell viability of leaves extract of A. crispa on 4T1 mammary cell lines after 72 hours of treatment.

\begin{tabular}{|c|c|c|c|c|c|c|c|}
\hline $\begin{array}{l}\text { Concentration } \\
(\mu \mathrm{g} / \mathrm{mL})\end{array}$ & 15.63 & 31.25 & 62.5 & 125 & 250 & 500 & 1000 \\
\hline $\begin{array}{l}80 \% \text { methanol } \\
\text { extract }\end{array}$ & $88.00 \pm 3.12^{*}$ & $60.63 \pm 1.97^{* * *}$ & $31.16 \pm 1.40^{* * *}$ & $13.35 \pm 1.51^{* * *}$ & $11.58 \pm 0.21^{* * *}$ & $12.95 \pm 4.34^{* * *}$ & $11.14 \pm 2.13^{* * *}$ \\
\hline $\begin{array}{l}\text { Ethyl acetate } \\
\text { extract }\end{array}$ & $97.08 \pm 5.73$ & $82.59 \pm 8.76^{* *}$ & $34.81 \pm 4.42^{* * *}$ & $8.98 \pm 0.43^{* * *}$ & $9.33 \pm 0.22^{* * *}$ & $9.58 \pm 1.40^{* * *}$ & $9.07 \pm 2.25^{* * *}$ \\
\hline $\begin{array}{l}\text { Aqueous } \\
\text { extract }\end{array}$ & $97.37 \pm 1.17$ & $91.59 \pm 3.80$ & $89.03 \pm 6.44^{*}$ & $66.13 \pm 2.99^{* * *}$ & $54.35 \pm 5.34^{* * *}$ & $38.26 \pm 2.08^{* * *}$ & $4.91 \pm 2.64^{* * *}$ \\
\hline
\end{tabular}

Values are expressed as mean \pm standard deviation $(n=3)$ per plate for three times' experiments. The comparison between treated cells and untreated cells (control) was evaluated using one-way ANOVA followed by Dunnett's multiple comparison test. ${ }^{*} P<0.05,{ }^{* *} P<0.01$, and ${ }^{* * *} P<0.001$ denote significant difference as compared to untreated cell (control).

TABLE 2: Percentage (\%) of cell survivability of leaves extract of A. crispa on normal mouse fibroblast cell line (NIH3T3) after 72 hours of treatment.

\begin{tabular}{|c|c|c|c|c|c|c|c|}
\hline $\begin{array}{l}\text { Concentration } \\
(\mu \mathrm{g} / \mathrm{mL})\end{array}$ & 15.63 & 31.25 & 62.5 & 125 & 250 & 500 & 1000 \\
\hline $\begin{array}{l}80 \% \text { methanol } \\
\text { extract }\end{array}$ & $100.28 \pm 5.05$ & $97.13 \pm 6.42$ & $92.46 \pm 4.00$ & $86.78 \pm 9.43$ & $67.34 \pm 20.53$ & $47.18 \pm 2.52^{* * *}$ & $\begin{array}{c}36.81 \pm \\
16.54^{* * *}\end{array}$ \\
\hline $\begin{array}{l}\text { Ethyl acetate } \\
\text { extract }\end{array}$ & $97.08 \pm 5.73$ & $82.59 \pm 8.76^{*}$ & $34.81 \pm 4.42^{* * *}$ & $8.98 \pm 0.43^{* * *}$ & $9.33 \pm 0.22^{* * *}$ & $9.58 \pm 1.40^{* * *}$ & $9.07 \pm 2.25^{* * *}$ \\
\hline $\begin{array}{l}\text { Aqueous } \\
\text { extract }\end{array}$ & $93.79 \pm 9.56$ & $76.48 \pm 2.84$ & $70.43 \pm 2.33^{* * *}$ & $63.36 \pm 2.51^{* * *}$ & $48.29 \pm 2.42^{* * *}$ & $35.93 \pm 2.50^{* * *}$ & $34.99 \pm 0.77^{* * *}$ \\
\hline
\end{tabular}

Values are expressed as mean \pm standard deviation $(n=3)$ per plate for three times' experiments. The comparison between treated cells and untreated cells (control) was evaluated using one-way ANOVA followed by Dunnett's multiple comparison test. ${ }^{*} P<0.05$ and ${ }^{* * *} P<0.001$ denote significant difference as compared to untreated cell (control).

were analysed using one-way ANOVA followed by Dunnett's multiple comparison test. The test was considered statistically significant when $P<0.05$ as compared to untreated cell (control) and GraphPad Prism Software 5.0 was used to analyse all statistical tests.

\section{Results}

Table 1 represents the percentage (\%) of cell viability of leaves extract of A. crispa on 4T1 mammary cancer cell lines while Table 2 represents the percentage (\%) of cell survivability of leaves extract of A. crispa on normal mouse fibroblast cell line (NIH3T3) after 72 hours of treatment, respectively. The cell viability of $4 \mathrm{Tl}$ against treatment with $A$. crispa and its solvent partitions were assessed using MTT assay. The inhibitory concentration $\left(\mathrm{IC}_{50}\right)$ and survivability $\left(\mathrm{CC}_{50}\right)$ of the cell versus various extract treatment were constructed through linear regression principle (Figures 1 and 2). The $\mathrm{IC}_{50}$ and $\mathrm{CC}_{50}$ values of $80 \%$ methanol extract, ethyl acetate extract, and aqueous extract were shown in Table 3 . The results demonstrated that $80 \%$ extract shows the highest inhibitory level on cancer cell and survivability rate on normal cell, making it able to be considered as a potential antimammary cancer agent.

The phytochemical screening results of $80 \%$ methanol extract and its partitions (ethyl acetate and aqueous extract) are displayed in Table 4 . Phytochemical constituents, namely, phenolics, flavonoids, saponins, tannins, and terpenoids, were determined with various standard screening tests. Overall, $80 \%$ methanol extract, ethyl acetate extract, and aqueous

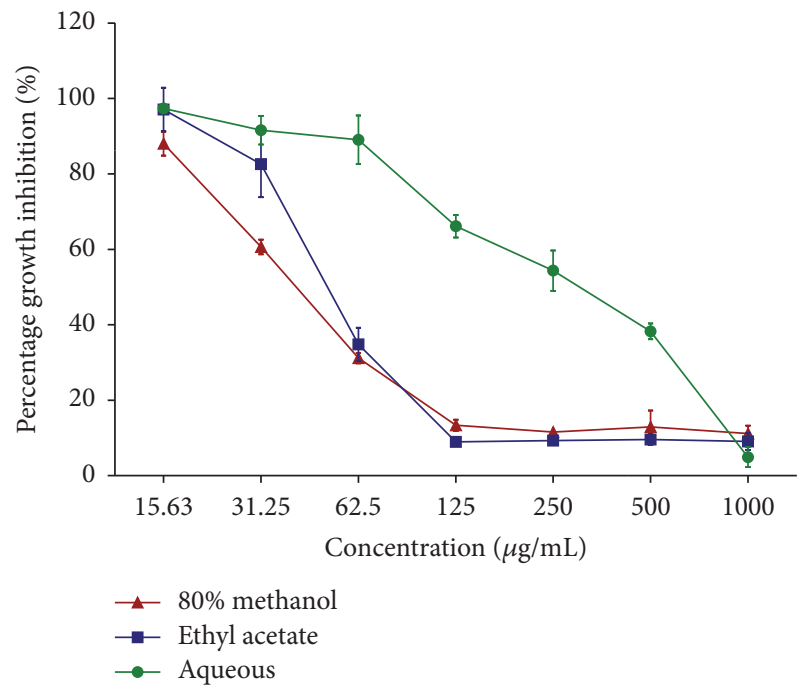

FIgURE 1: Growth inhibition of $A$. crispa leaves extract on 4T1 mammary carcinoma cell line after 72 hours of treatment. Every point denotes mean $(n=3)$ of triplicate sample. Error bars indicate standard deviation.

extract contain all the phytochemicals listed in Table 4 except for saponins in aqueous extract.

3.1. Apoptosis Detection with Dual Fluorescent Staining. Figure 3 is the representative picture of the treated and untreated 4T1 mammary cancer cells after 72 hours of 


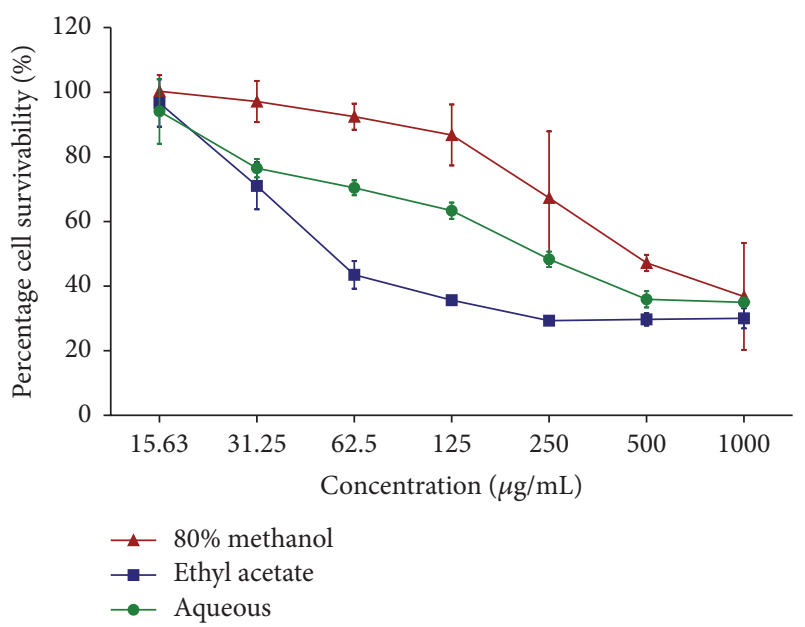

FIgURE 2: Cell survivability of A. crispa leaves extracts on normal mouse fibroblast cell line (NIH3T3) after 72 hours of treatment. Every point denotes mean $(n=3)$ of triplicate sample. Error bars indicate standard deviation.

TABLE 3: $\mathrm{IC}_{50}$ and $\mathrm{CC}_{50}$ and selective index of $80 \%$ methanol, ethyl acetate, and aqueous extracts.

\begin{tabular}{lccc}
\hline $\begin{array}{l}\text { Types of } \\
\text { extract }\end{array}$ & $\begin{array}{c}\mathrm{IC}_{50} \text { on } 4 \mathrm{~T} 1 \\
(\mu \mathrm{g} / \mathrm{mL})\end{array}$ & $\begin{array}{c}\mathrm{CC}_{50} \text { on NIH3T3 } \\
(\mu \mathrm{g} / \mathrm{mL})\end{array}$ & SI \\
\hline $80 \%$ methanol & $42.26 \pm 1.82$ & $431.94 \pm 93.11$ & 10.22 \\
Ethyl acetate & $52.41 \pm 3.49$ & $50.21 \pm 1.35$ & 0.96 \\
Aqueous & $303.09 \pm 48.08$ & $236.42 \pm 16.94$ & 0.78 \\
\hline
\end{tabular}

Values are expressed as mean \pm standard deviation $(n=3)$ per plate for three times' experiments.

treatment with $\mathrm{IC}_{50}$ value from $80 \%$ methanol extract, stained with dual staining acridine orange/propidium iodide (AO/PI). Based on MTT assay, it showed that $80 \%$ ethanol extract is the best extract and the $\mathrm{IC}_{50}$ against $4 \mathrm{~T} 1$ mammary cancer cells was the lowest where $\mathrm{IC}_{50}$ value is $42.26 \mu \mathrm{g} / \mathrm{mL}$. Therefore, AO/PI dual fluorescent staining assay was performed on 4T1 mammary cancer cell line. Majority of untreated cells emitted green fluorescence colour. The treated cells emitted red fluorescence colour indicating that the cell death is due to necrosis event, whereby the PI dye remains bound to the nucleated dead cells. The green fluorescence colour is indicating that the cell is alive and the AO dye permeable to it, whereas orange colour is indicating apoptotic cells due to apoptosis event. Besides the colour emission from the staining, the morphology, number, and size of the cells were also determined before and after treatment. For untreated cells, the cells were uniform in size and morphology. For treated cells, the size was not uniform. The number of cells also reduced and the morphological appearance of the cells was showing shrinkage.

3.2. Quantitative Apoptosis Analysis Using Flow Cytometer. Event of apoptosis was confirmed quantitatively using flow cytometer machine. The cells were labelled with Annexin VFITC and/or propidium iodide (PI) dyes. Six hours and 24 hours were selected to evaluate how soon the extract is able
TABle 4: Phytochemical constituent of different extracts of A. crispa leaves.

\begin{tabular}{lcc}
\hline $\begin{array}{l}\text { Phytochemical } \\
\text { constituent }\end{array}$ & Sample & Result \\
\hline \multirow{3}{*}{ Phenolics } & Hydromethanol extract & ++ \\
& Ethyl acetate extract & +++ \\
& Aqueous extract & + \\
\hline \multirow{2}{*}{ Flavonoids } & Hydromethanol extract & ++ \\
& Ethyl acetate extract & +++ \\
& Aqueous extract & + \\
Saponins & Hydromethanol extract & ++ \\
& Ethyl acetate extract & + \\
& Aqueous extract & - \\
Tannins & Hydromethanol extract & ++ \\
& Ethyl acetate extract & +++ \\
& Aqueous extract & + \\
\hline \multirow{2}{*}{ Terpenoids } & Hydromethanol extract & + \\
& Ethyl acetate extract & ++ \\
& Aqueous extract & + \\
\hline
\end{tabular}

For phenolic, flavonoids, tannin, and terpenoids, -: no colour; +: weak colour; ++: moderate colour; +++: intense colour.

For saponin, -: no froth for 10 minutes; $+: 1-2 \mathrm{~cm}$ froth maintained for 5 minutes; ++: $2-3 \mathrm{~cm}$ froth maintained for 10 minutes; $+++: 3 \mathrm{~cm}$ and more froth maintained for $10 \mathrm{~min}$.

to induce apoptosis. Figure 4 represents apoptosis event that occurs following treatment with $80 \%$ methanol of A. crispa extract. Table 5 shows the percentage (\%) of distribution of apoptosis events before and after treatment. The cells were differentiated into four quadrates based on the cell stages: viable, early apoptosis, late apoptosis, and necrosis quadrates.

At 6 hours and 24 hours of treatment, $80 \%$ methanol extract induced apoptosis to treated 4T1 mammary cell lines though without statistical significance $(P>0.05)$. The result shows that $A$. crispa are able to induce apoptosis as early as 6 hours following treatment with $80 \%$ methanol extract at their respective $\mathrm{IC}_{50}$ value. In control (untreated cells), there was no apoptosis event occurrence $(0 \%)$ claiming that the plant is the source of apoptosis inducing event to occur. As the time of treatment increased to 24 hours, the percentage of apoptotic cells (early and late) also increased proportional to time of exposure.

\section{Discussion}

This study was aimed to investigate the potential cytotoxicity activity of A. crispa against Mus musculus mammary carcinoma cell line (4T1) in vitro. The leaves of A. crispa were extracted using $80 \%$ methanol, followed with solvent partitioning with ethyl acetate and aqueous extract. The cytotoxicity of the different extracts against $4 \mathrm{~T} 1$ cells were assessed using cell based colourmetric assay, (3-(4,5-dimethylthiazol2-yl)-2,5-diphenyltetrazolium bromide) MTT assay [20, 21]. The cytotoxicity classification was sorting based on United State National Cancer Institute (USNCI) plant screening program. $\mathrm{IC}_{50}$ value of extract that is between 20 and $100 \mu \mathrm{g} / \mathrm{mL}$ 
TABLE 5: Percentage (\%) of viable cells, early apoptosis, late apoptosis and necrosis of $4 \mathrm{~T} 1$ cells following treatment at their respective $\mathrm{IC}_{50}$ after 6 and 24 hours.

\begin{tabular}{lcccc}
\hline & \multicolumn{4}{c}{ Percentage (\%) of 4T1 mammary cells at different time points } \\
& Viable cells & Early apoptosis & Late apoptosis & Necrosis \\
\hline Control (untreated) & $98.00 \pm 2.08$ & $0.17 \pm 0.15$ & $0.00 \pm 0.00$ & $1.87 \pm 2.11$ \\
$\mathrm{IC}_{50}$ at 6 hours & $81.30 \pm 2.26$ & $8.30 \pm 1.11$ & $0.70 \pm 0.42$ & $9.70 \pm 4.95$ \\
$\mathrm{IC}_{50}$ at 24 hours & $30.90 \pm 1.61$ & $0.8 \pm 0.10$ & $3.82 \pm 1.44$ & $30.10 \pm 0.26$ \\
\hline
\end{tabular}

All data are expressed as mean \pm SD (standard deviation).

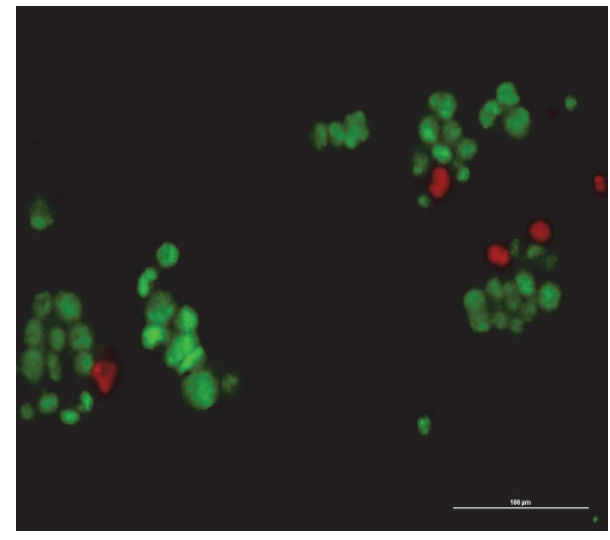

(a)

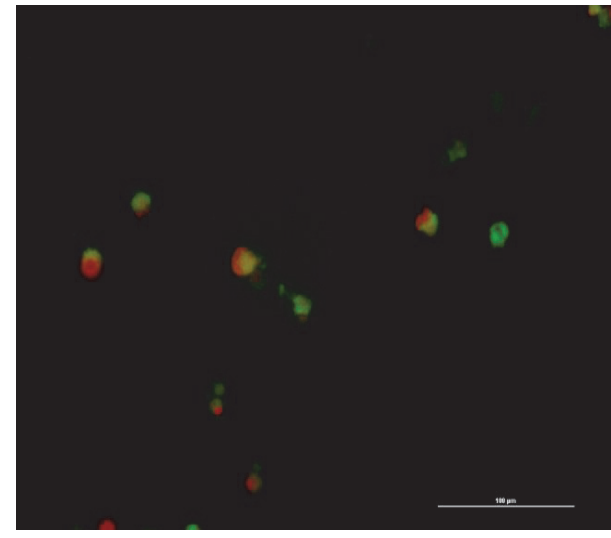

(b)

FIGURE 3: $4 \mathrm{~T} 1$ cells stained with dual staining AO/PI following treatment with $80 \%$ methanol extract for 72 hours. The cells were viewed under inverted research fluorescence microscope (Nikon ECLIPSE Ti-S, Shinagawa-ku, Tokyo, Japan) at 20x magnification. (a) Control (untreated $4 \mathrm{~T} 1$ cells) being majorly viable and uniform in shape. Green fluorescent colour indicates cells are viable. (b) $4 \mathrm{~T} 1 \mathrm{cells}$ treated with $42.26 \mu \mathrm{g} / \mathrm{mL}$ of $80 \%$ methanol extract. Red colour indicates cells that had undergone necrosis while orange colour indicates cells that had undergone apoptosis. Number of viable cells was reduced and cells were showing shrinkage. Scale bars represent $100 \mu \mathrm{m}$.

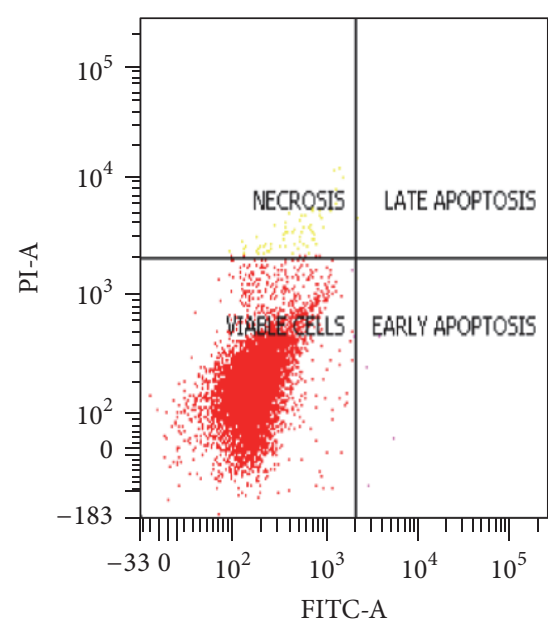

(a)

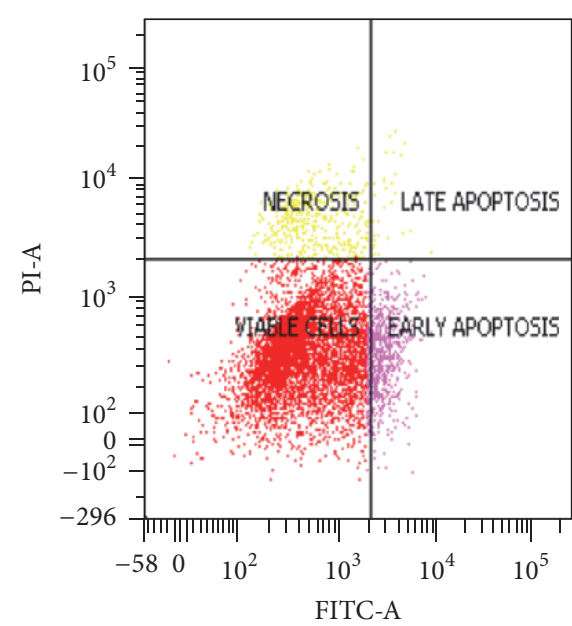

(b)

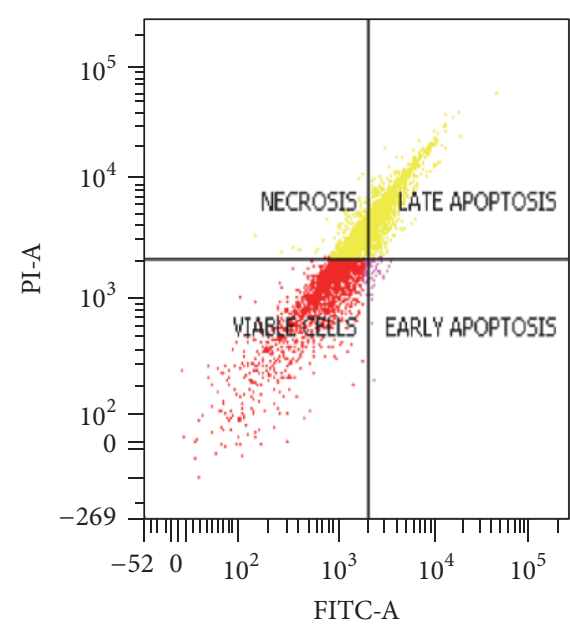

(c)

FIGURE 4: Apoptosis event occurs following treatment with $80 \%$ methanol extract at their respective $\mathrm{IC}_{50}$ after 6 and 24 hours. (a) Control (untreated cells) with no apoptosis event occurrence. (b) and (c) are treated cells after 6 and 24 hours, respectively. The apoptosis event occurs as early as 6 hours after treatment with $80 \%$ methanol extract.

is considered moderately cytotoxic $[11,22,23]$ while less than $20 \mu \mathrm{g} / \mathrm{mL}$ is considered strongly cytotoxic [23, 24].

Among $80 \%$ methanol, ethyl acetate, and aqueous extracts, $80 \%$ methanol extract showed the lowest $\mathrm{IC}_{50}$ value with $42.26 \pm 1.82 \mu \mathrm{g} / \mathrm{mL}$. Analysis from the solvent partitioning revealed that ethyl acetate showed lower $\mathrm{IC}_{50}$ value with $52.41 \pm 3.49 \mu \mathrm{g} / \mathrm{mL}$ compared to aqueous extract which was $303.09 \pm 48.09 \mu \mathrm{g} / \mathrm{mL}$. The results showed that as $80 \%$ methanol extract underwent solvent partitioning with ethyl acetate and aqueous extract, the $\mathrm{IC}_{50}$ values are getting 
higher indicating that cytotoxicity effect is weak. The $80 \%$ methanol extraction showed the best and most promising anticancer activity as compared to ethyl acetate and aqueous extracts. Further studies on mode of cell death of $80 \%$ methanol extraction were conducted.

In the present preliminary analysis for phytochemical compounds of $80 \%$ methanol extract from leaves, the results reported the presence of phenolic, flavonoid, saponin, tannin, terpenoid, and steroid. In the interest of narrowing down the phytochemical compounds with different polarity, the crude $80 \%$ methanol extract was further purified with solvent partitioning method with ethyl acetate (EA) and aqueous (AQ) extract. $80 \%$ methanol and ethyl acetate extracts revealed more phytochemical compounds as compared to aqueous extract. This result explained the weakest cytotoxicity effect exhibited by aqueous extract. The study conducted in [2] revealed that the root of Ardisia contains various phytochemical compounds such as phenolic, flavonoid, and saponin using hydroethanolic extract as solvent system. Results of this study also confirmed the findings of previous studies that pure alcoholic solvents like ethanol and methanol alone are not a preferable solvent system compared to the mixture of ethanol or methanol with water which is more effective especially in extracting phytochemical components from medicinal plants $[25,26]$.

Phytochemical compounds are plant secondary metabolites that are present in all plant species either in a mixture or alone but the amount differs between species. The phytochemical compound is not directly involved in plant growth and reproduction; however, their presence is crucially important in the plant defence systems against bacteria, fungus, virus, and free radicals. In application with that, the phytochemical compound of the plant has widely been extracted and used in healthcare products, cosmetics, and food flavouring industries [27]. Examples of the phytochemical compounds of plant origin which appeared to provide promising health benefit effects are phenolic, flavonoid, saponin, tannin, and terpenoid.

The phytochemical constituents that existed in A. crispa and its fractions play significant role in the ethnopharmacological medicinal values of the plants. Phenolics are the largest group of secondary plant metabolites that exhibits potent antioxidant and anticancer properties and is mostly found in plant-origin foods [28]. Flavonoids are a derivative of phenolic that have antitumour, antioxidant, and antiinflammatory activity. Tannins have antiviral, antibacterial, and antiparasitic effects and anti-inflammatory, antiulcer, and antioxidant properties [29-31]. Saponins are known to have antimicrobial, anti-inflammatory [32], and anticancer activities [33].

$80 \%$ methanol is known to be an efficient and widely used solvent system to extract natural antioxidative components, especially the phenolics, from plant materials. This is due to the fact that the methanol-water mixture has high polarity and thus greater efficacy towards the extraction of polar phytochemicals such as phenolics and flavonoids. Plants that contain high phenolic and flavonoid compounds are able to induce apoptosis and cell cycle arrest which is part of the mechanism of action [34]. The fact that $80 \%$ methanol extract of A. crispa has a good anticancer activity has been influenced by the selection of solvent. Similar results were also reported previously $[25,35,36]$ and thus support this recent finding. The choice of extraction solvents such as water, acetone, ethyl acetate, alcohols (methanol, ethanol, and propanol), and their mixtures will influence the yields of phenolics extracted [37].

The results showed that as the $80 \%$ methanol extract undergoes partition with ethyl acetate and aqueous solution, the $\mathrm{IC}_{50}$ value is getting higher and selectivity index is getting lower which was not a good criterion of anticancer agent $[38,39] .80 \%$ methanol extract was considered to have a low cytotoxicity to normal cells; meanwhile ethyl acetate extract was considered cytotoxic to both cancer and normal cells and aqueous extract was considered to have poor cytotoxicity effect. The $80 \%$ methanol extract of $A$. crispa can be classified as a good potential for antimammary cancer agent, safe, and generally not toxic to mammal cells when the selectivity index value is more than 2.0. The differences in $\mathrm{CC}_{50}$ among extracts could be due to certain phytochemical compounds that exist in the extract that act differently towards cells since phytochemical compounds that exist in plants are of multicomponent mixture. Thus, separation of the phytochemical compounds provides difference cytotoxic response [40]. It also can be influenced by the solvent used that makes some compounds soluble and some not soluble in particular solvent [41]. This is because phenolic compounds have broad secondary plant metabolites with many subgroups/classes and usually combined with other substances [40,42]. It might be during partitioning of $80 \%$ methanol extract with ethyl acetate and aqueous extract that the chemical characteristic or solubility of phytochemical composition was altered. In a previous study, 6 Ardisia species that have been evaluated (A. crenata, A. escallonioides, A. mamillata, A. Japonica, A. compressa, and A. elliptica) showed that the plant is significantly cytotoxic to hepatocellular carcinoma cell (HepG2) and the plant contains high phenolics compound [43]. In this current study, it is strongly believed that the mechanism underlying the anticancer effects was through the phenolics content. The plant that contains high phenolic and flavonoid compounds induces apoptosis and cell cycle arrest which is part of mechanism of action [34]. However, apoptosis assessment and cell cycle analysis are needed to be conducted in order to prove the mechanism of action.

Qualitative and quantitative methods were conducted to understand the mode of cell death and mechanism of action of the extract to cause cytotoxic effect to the mammary cancer cells. The antimammary cancer activity of extract was further supported with microscopic apoptosis evaluation by $\mathrm{AO} / \mathrm{PI}$ dual fluorescent staining and quantification apoptosis analysis using Annexin V-FITC/PI staining. Furthermore, the morphological changes of $4 \mathrm{~T} 1$ mammary cancer cells before and after treatment observed under inverted fluorescence microscope also support the finding grossly. The qualitative and quantitative analyses of apoptosis event are significantly important in order to determine and confirm the mechanism of action played by the extract [44].

Apoptosis is an important criterion for a potential anticancer agent. To confirm the detailed apoptosis event of the extract, flow cytometry analysis was performed. The cells 
were labelled with Annexin V-FITC and propidium iodide. Annexin V-FITC is a type of dye that has high affinity towards phosphatidylserine (PS) in the plasma membrane of cell. During apoptosis event, the plasma membrane of the cells becomes asymmetrical and loses its integrity, thus resulting in translocation of PS to the outer plasma membrane. This condition can be detected with Annexin V-FITC which is a type of calcium-dependent phospholipid-binding proteins and allowed permeability of dyes to PS and emits fluorescent colour which can be counted by flow cytometry machine. Since Annexin V is typically used for early apoptosis event, using it in conjunction with propidium iodide (PI) is really recommended for identification of early and late apoptotic cells because dead cells are permeable to PI. According to [45], most chemotherapeutic drugs are able to induce apoptosis within 3-24 hours. Interestingly, in this study, even though $80 \%$ methanol extract was considered as an extract, it was able to induce apoptosis event this fast, within 6-24 hours and in comparison to other chemotherapeutic drugs.

The regulation of apoptosis plays an important role in the development of antineoplastic drug. Imperfection of apoptosis modulation would impair body defence system and can initiate cancer development or continues cancer cell proliferation. No studies had been conducted on the apoptosis pathway specifically from the leaves of A. crispa on mammary cancer but previous study from [46] showed that ardisin (type of alkylphenols) from root extracts of Ardisia brevicaulis demonstrated cytotoxic effect against human lung cancer cells by inducing apoptosis pathway with G1 phase cell cycle arrest. Reference [43] stated that 6 species of Ardisia (A. Compressa, A. Japonica, A. Elliptica, A. Crenata, and A. mamillata) have cytotoxicity against human liver cancer (HepG2) through apoptosis mechanism. Hence, the results from previous studies support the current findings, linking phenolics and cytotoxic activity of Ardisia crispa with antimammary effect. Therefore, comprehensive studies are required intensively involving animal and clinical studies in order to elucidate the true potential of this plant.

\section{Conclusion}

Based on the result of this study, $80 \%$ methanol extraction of A. crispa can be considered as good antimammary cancer agent with high selectivity index. The high selectivity index showed ideal characteristic of anticancer agent, claiming that the $80 \%$ methanol extract of A. crispa is able to recognize between cancer and normal cells before killing it. These findings indicate the potential medicinal value of A. crispa in terms of cancer therapy and prevention. In vivo study and isolation of bioactive compound would provide more validation for impetus studies associated with inhibition and apoptotic effects against mammary cancer.

\section{Conflicts of Interest}

The authors declare that there are no conflicts of interest regarding the publication of this paper.

\section{Acknowledgments}

The authors wish to thank the Faculty of Veterinary Medicine and Faculty of Medicine and Health Sciences, Universiti Putra Malaysia, for providing the facilities to carry out this study. This research was funded by RUGS, UPM (01-02-121670RU).

\section{References}

[1] W. Christophe, Medicinal Plants of Southeast Asia, Prentice Hall, Petaling Jaya, Malaysia, 2002.

[2] D. E. Z. A. Hamsin, R. A. Hamid, L. S. Yazan, C. N. M. Taib, and Y. L. Ting, "The hexane fraction of Ardisia crispa Thunb. A. DC. roots inhibits inflammation-induced angiogenesis," BMC Complementary and Alternative Medicine, vol. 13, article no. 5, 2013.

[3] A. H. Roslida and K. H. Kim, "Research article: Antiinflammatory and anti-hyperalgesic effects of Ardisia crispa Thunb. D.C," Pharmacognosy Magazine, vol. 4, no. 16, pp. 262268, 2008 .

[4] A. H. Roslida, Y. H. Teh, and K. H. Kim, "Evaluation of antiulcer activity of Ardisia crispa Thunb. DC," Pharmacognosy Research, vol. 1, no. 5, pp. 250-255, 2009.

[5] Y.-H. Kang, W. H. Kim, M. K. Park, and B. H. Han, "Antimetastatic and antitumor effects of benzoquinonoid AC7-1 from Ardisia crispa," International Journal of Cancer, vol. 93, no. 5, pp. 736-740, 2001.

[6] A. H. Roslida, O. Fezah, and L. T. Yeong, "Suppression of DMBA/croton oil-induced mouse skin tumor promotion by Ardisia crispa root hexane extract," Asian Pacific Journal of Cancer Prevention, vol. 12, no. 3, pp. 665-669, 2011.

[7] H. Sulaiman, R. A. Hamid, Y. L. Ting, and F. Othman, "Anti-tumor effect of Ardisia crispa hexane fraction on 7, 12dimethylbenz $[\alpha]$ anthracene-induced mouse skin papillomagenesis," Journal of Cancer Research and Therapeutics, vol. 8, no. 3, pp. 404-410, 2012.

[8] A. Jemal, F. Bray, M. M. Center, J. Ferlay, E. Ward, and D. Forman, "Global cancer statistics," CA: A Cancer Journal for Clinicians, vol. 61, no. 2, pp. 69-90, 2011.

[9] Z. A. Zakaria, A. M. Mohamed, N. S. M. Jamil et al., "In vitro antiproliferative and antioxidant activities of the extracts of Muntingia calabura leaves," The American Journal of Chinese Medicine, vol. 39, no. 1, pp. 183-200, 2011.

[10] Z. Ayob, S. P. Mohd Bohari, A. Abd Samad, and S. Jamil, "Cytotoxic activities against breast cancer cells of local Justicia gendarussa crude extracts," Evidence-Based Complementary and Alternative Medicine, vol. 2014, Article ID 732980, 12 pages, 2014.

[11] Z. Baharum, A. M. Akim, Y. H. Taufiq-Yap, R. A. Hamid, and R. Kasran, "In vitro antioxidant and antiproliferative activities of methanolic plant part extracts of Theobroma cacao," Molecules, vol. 19, no. 11, pp. 18317-18331, 2014.

[12] P. Senthilraja and K. Kathiresan, "In vitro cytotoxicity MTT assay in Vero, HepG2 and MCF-7 cell lines study of Marine Yeast," Journal of Applied Pharmaceutical Science, vol. 5, no. 3, pp. 80-84, 2015.

[13] Y. Gavamukulya, F. Abou-Elella, F. Wamunyokoli, and H. AElShemy, "Phytochemical screening, anti-oxidant activity and in vitro anticancer potential of ethanolic and water leaves extracts of Annona muricata (Graviola)," Asian Pacific Journal of Tropical Medicine, vol. 7, no. 1, pp. S355-S363, 2014. 
[14] J. D. Lambert and R. J. Elias, "The antioxidant and pro-oxidant activities of green tea polyphenols: a role in cancer prevention," Archives of Biochemistry and Biophysics, vol. 501, no. 1, pp. 6572, 2010.

[15] R. Govindarajan, M. Vijayakumar, and P. Pushpangadan, "Antioxidant approach to disease management and the role of 'Rasayana' herbs of Ayurveda," Journal of Ethnopharmacology, vol. 99, no. 2, pp. 165-178, 2005.

[16] P. Tiwari, B. Kumar, M. Kaur, G. Kaur, and H. Kaur, "Review of phytochemical screening and extraction process," Internationale Pharmaceutica Sciencia, vol. 1, no. 1, pp. 25-30, 2011.

[17] Z. Khanam, C. S. Wen, and I. U. H. Bhat, "Phytochemical screening and antimicrobial activity of root and stem extracts of wild Eurycoma longifolia Jack (Tongkat Ali)," Journal of King Saud University-Science, vol. 27, no. 1, pp. 23-30, 2015.

[18] H. O. Edeoga, D. E. Okwu, and B. O. Mbaebie, "Phytochemical constituents of some Nigerian medicinal plants," African Journal of Biotechnology, vol. 4, no. 7, pp. 685-688, 2005.

[19] R. N. S. Yadav and M. Agarwala, "Phytochemical analysis of some medicinal plants," Journal of Phytology, vol. 3, no. 12, 2011.

[20] R. I. Freshney, Culture of Animal Cells: A Manual of Basic Techniques, John Wiley \& Sons, New Jersey, NJ, USA, 5th edition, 2005.

[21] J. A. Plumb, “The MTT assay," in Cancer Cell Culture: Methods and Protocols, vol. 88 of Methods in Molecular Medicine, pp. 165169, Humana Press, Totowa, NJ, USA, 2004.

[22] K. Atjanasuppat, W. Wongkham, P. Meepowpan et al., "In vitro screening for anthelmintic and antitumour activity of ethnomedicinal plants from Thailand," Journal of Ethnopharmacology, vol. 123, no. 3, pp. 475-482, 2009.

[23] J. Boik, Natural Compounds in Cancer Therapy, Oregon Medical Press, Princeton, Minn, USA, 2001.

[24] S. Vijayarathna and S. Sasidharan, "Cytotoxicity of methanol extracts of Elaeis guineensis on MCF-7 and Vero cell lines," Asian Pacific Journal of Tropical Biomedicine, vol. 2, no. 10, pp. 826-829, 2012.

[25] A. Aktumsek, G. Zengin, G. O. Guler, Y. S. Cakmak, and A. Duran, "Antioxidant potentials and anticholinesterase activities of methanolic and aqueous extracts of three endemic CentaureaL. species," Food and Chemical Toxicology, vol. 55, pp. 290296, 2013.

[26] G. Shabir, F. Anwar, B. Sultana et al., "Antioxidant and antimicrobial attributes and phenolics of different solvent extracts from leaves, flowers and bark of gold mohar [Delonix regia (Bojer ex Hook.) Raf.]," Molecules, vol. 16, no. 9, pp. 7302-7319, 2011.

[27] H. Aoyagi, "Application of plant protoplasts for the production of useful metabolites," Biochemical Engineering Journal, vol. 56, no. 1-2, pp. 1-8, 2011.

[28] R. Tsao, "Chemistry and biochemistry of dietary polyphenols," Nutrients, vol. 2, no. 12, pp. 1231-1246, 2010.

[29] H. Kolodziej and A. F. Kiderlen, "Antileishmanial activity and immune modulatory effects of tannins and related compounds on Leishmania parasitised RAW 264.7 cells," Phytochemistry, vol. 66, no. 17, pp. 2056-2071, 2005.

[30] T. Nakagawa and T. Yokozawa, "Direct scavenging of nitric oxide and superoxide by green tea," Food and Chemical Toxicology, vol. 40, no. 12, pp. 1745-1750, 2002.
[31] S. D. Kapu, Y. B. Ngwai, O. Kayode, P. A. Akah, C. Wambebe, and K. Gamaniel, "Anti-inflammatory, analgesic and antilymphocytic activities of the aqueous extract of Crinum giganteum," Journal of Ethnopharmacology, vol. 78, no. 1, pp. 7-13, 2001.

[32] G. Francis, Z. Kerem, H. P. S. Makkar, and K. Becker, "The biological action of saponins in animal systems: a review," British Journal of Nutrition, vol. 88, no. 6, pp. 587-605, 2002.

[33] M.-Y. Xu, D. H. Lee, E. J. Joo, K. H. Son, and Y. S. Kim, "Akebia saponin PA induces autophagic and apoptotic cell death in AGS human gastric cancer cells," Food and Chemical Toxicology, vol. 59, pp. 703-708, 2013.

[34] S. Machana, N. Weerapreeyakul, S. Barusrux, A. Nonpunya, B. Sripanidkulchai, and T. Thitimetharoch, "Cytotoxic and apoptotic effects of six herbal plants against the human hepatocarcinoma (HepG2) cell line," Chinese Medicine, vol. 6, article no. 39, 2011.

[35] J. Seo, S. Lee, M. L. Elam, S. A. Johnson, J. Kang, and B. H. Arjmandi, "Study to find the best extraction solvent for use with guava leaves (Psidium guajava L.) for high antioxidant efficacy," Food Science \& Nutrition, vol. 2, no. 2, pp. 174-180, 2014.

[36] F. Anwar and R. Przybylski, "Effect of solvents extraction on total phenolics and antioxidant activity of extracts from flaxseed (Linum usitatissimum L.)," Acta Scientiarum Polonorum, Technologia Alimentaria, vol. 11, no. 3, pp. 293-302, 2012.

[37] P. Garcia-Salas, A. Morales-Soto, A. Segura-Carretero, and A. Fernández-Gutiérrez, "Phenolic-compound-extraction systems for fruit and vegetable samples," Molecules, vol. 15, no. 12, pp. 8813-8826, 2010.

[38] W. Al-Rashidi, N. N. Mat Supri, and N. Manshoor, "Cytotoxic activity of crude extract from Costus malortieanus (Costaceae)," American-Eurasian Journal of Toxicological Sciences, vol. 3, no. 2, pp. 63-66, 2011.

[39] Y. Saidu, F. Nwachukwu, L. Bilbis, U. Faruk, and A. Abbas, "Toxicity studies of the crude aqueous root extract of albizzia chevalieri harms in albino rats," Nigerian Journal of Basic and Applied Sciences, vol. 18, no. 2, 2010.

[40] S. Sasidharan, Y. Chen, D. Saravanan, K. M. Sundram, and L. Yoga Latha, "Extraction, isolation and characterization of bioactive compounds from plants' extracts," African Journal of Traditional, Complementary and Alternative Medicines, vol. 8, no. 1, pp. 1-10, 2011.

[41] B. Sultana, F. Anwar, and M. Ashraf, "Effect of extraction solvent/technique on the antioxidant activity of selected medicinal plant extracts," Molecules, vol. 14, no. 6, pp. 2167-2180, 2009.

[42] B. Drużyńska, A. Stępniewska, and R. Wołosiak, "The influence of time and type of solvent on efficiency of the extraction of polyphenols from green tea and antioxidantproperties obtained extracts," ACTA Scientiarum Polonorum Technologia Alimentaria, vol. 6, no. 1, pp. 27-36, 2007.

[43] A. M. B. Newell, G. G. Yousef, M. A. Lila, M. V. Ramírez-Mares, and E. G. de Mejia, "Comparative in vitro bioactivities of tea extracts from six species of Ardisia and their effect on growth inhibition of HepG2 cells," Journal of Ethnopharmacology, vol. 130, no. 3, pp. 536-544, 2010.

[44] D. Tao, J. Wu, Y. Feng, J. Qin, J. Hu, and J. Gong, "New method for the analysis of cell cycle-specific apoptosis," Cytometry Part A, vol. 57, no. 2, pp. 70-74, 2004.

[45] Y. Sheng, R. W. Pero, A. Amiri, and C. Bryngelsson, "Induction of apoptosis and inhibition of proliferation in human tumor cells treated with extracts of Uncaria tomentosa," Anticancer Research, vol. 18, no. 5, pp. 3363-3368, 1998. 
[46] G.-Y. Zhu, B. C. K. Wong, A. Lu et al., "Alkylphenols from the roots of Ardisia brevicaulis induce G1 arrest and apoptosis through endoplasmic reticulum stress pathway in human nonsmall-cell lung cancer cells," Chemical and Pharmaceutical Bulletin, vol. 60, no. 8, pp. 1029-1036, 2012. 


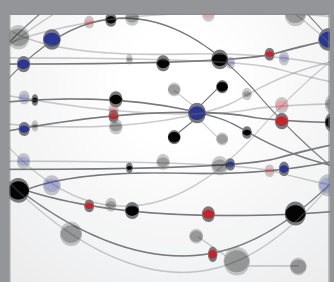

The Scientific World Journal
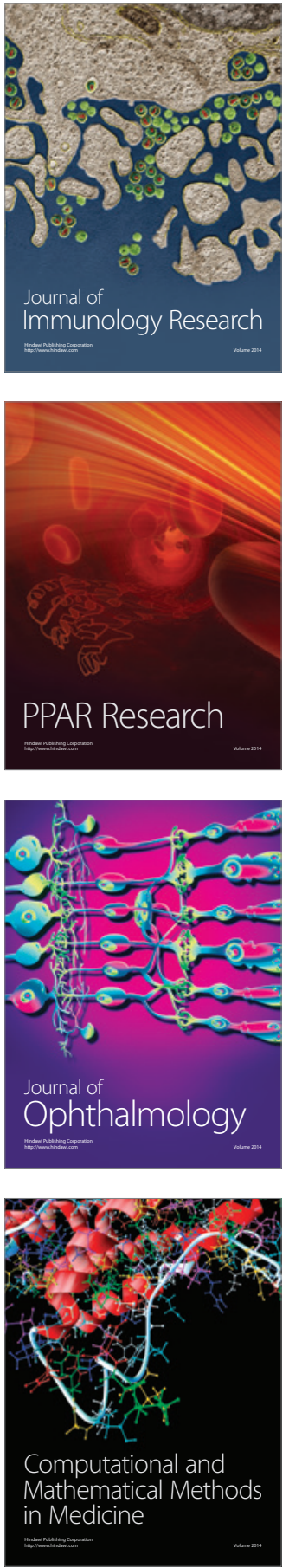

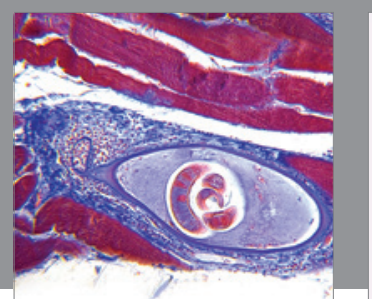

Gastroenterology Research and Practice
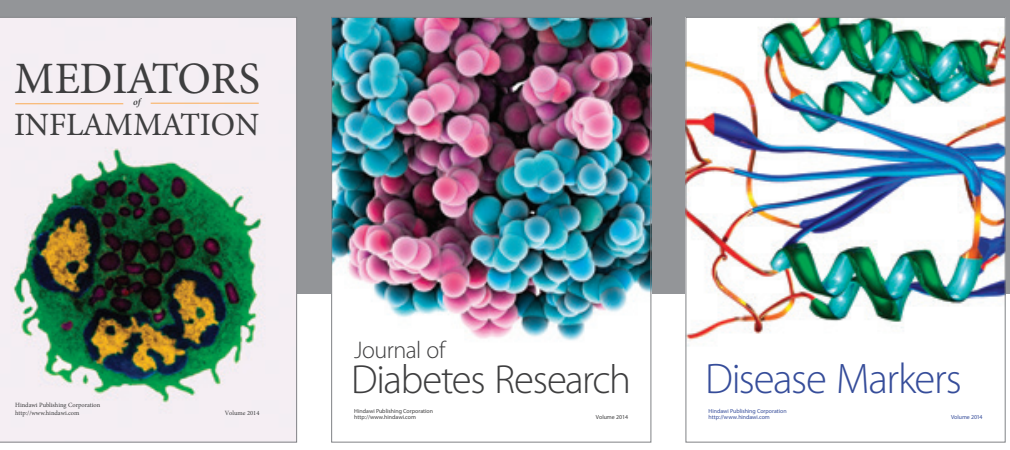

Disease Markers

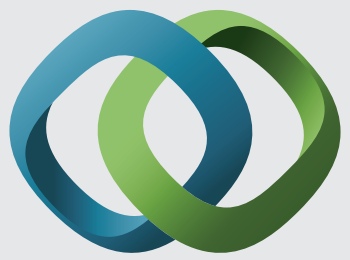

\section{Hindawi}

Submit your manuscripts at

https://www.hindawi.com
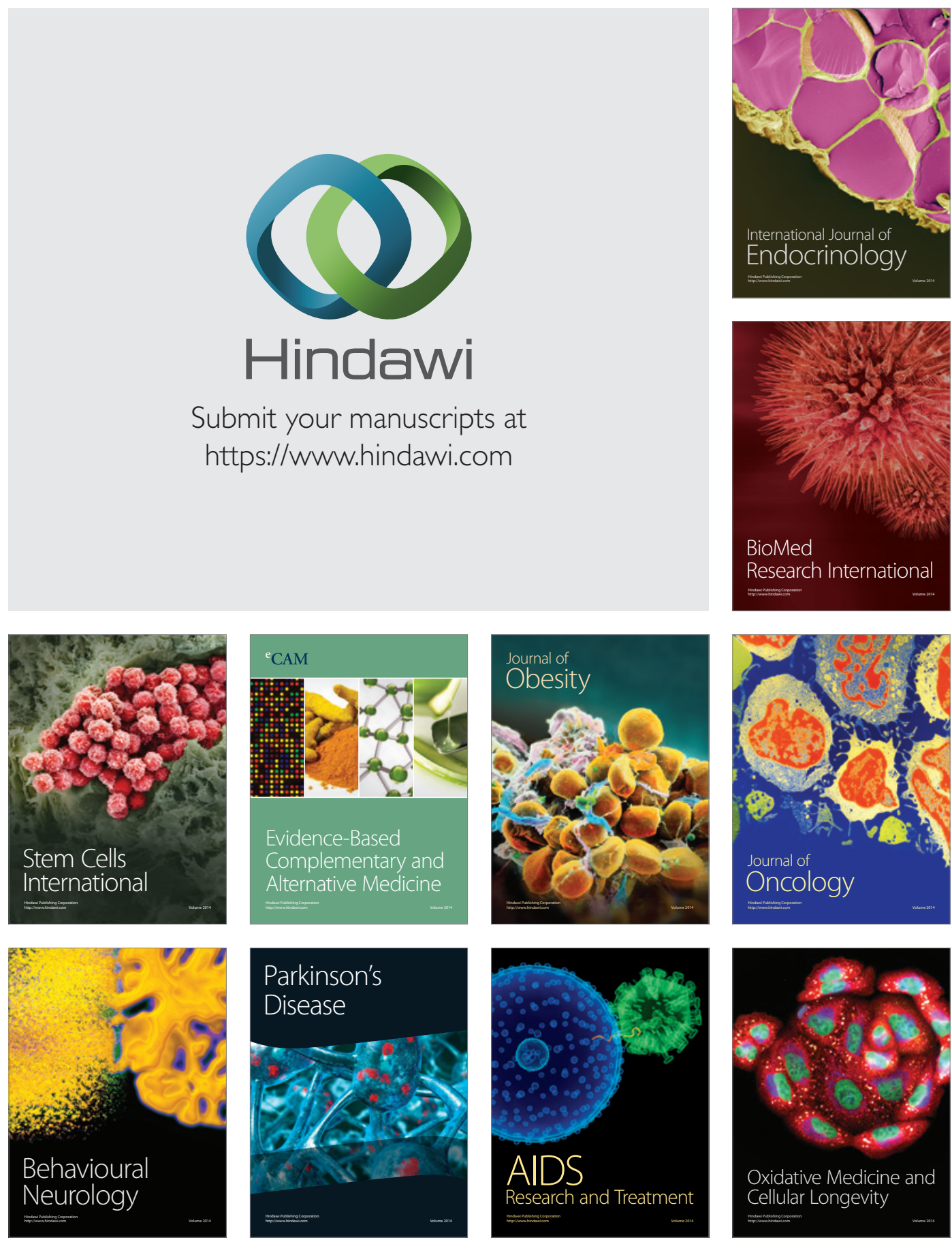